\title{
ICE SHELVES: A REVIEW
}

\author{
By Robert H. Thomas \\ (Institute for Quaternary Studies, University of Maine at Orono, Orono, Maine 04473, \\ U.S.A.)
}

Aвstract. Ice shelves form where ice flows off the Antarctic ice sheet onto the sea to produce rather flat slabs of floating ice which, for the theoretician, are the simplest of all large ice masses. Boundary conditions are well defined, conditions change very slowly over distances that are large compared with ice thickness, and horizontal velocities are independent of depth. Unconfined ice shelves can be used as giant creep machines to investigate the ice flow law at low stresses. Further inland, where movement is hampered by obstructions such as grounded ice rises and by shear between the ice shelf and its sides, the ice shelf transmits a backpressure which tends to restrict drainage from the ice sheets that feed it. Wastage from ice shelves is principally by calving and by bottom melting. There has been no direct measurement of bottom-melting rates, but indirect evidence suggests that, near the seaward edges of ice shelves, bottom-melting rates may exceed one metre per year, with significant melting within about $100 \mathrm{~km}$ of the ice front. Further inland there may be bottom freezing, and analysis of cores taken from the Amery Ice Shelf indicate that bottom-freezing rates average $0.5 \mathrm{~m} \mathrm{a}^{-1}$ over a distance of $200 \mathrm{~km}$. Such high freezing-rates are probably exceptional, and, beneath the Ross Ice Shelf, freezing appears to be insignificant even at a distance of $400 \mathrm{~km}$ from the ice front.

Because of their accessibility ice shelves have been studied in considerable detail, but many problems remain. In particular we need to improve our understanding of basal flux, ice-shelf dynamics near the grounding line, the calving of icebergs, and the state of equilibrium of ice rises. In addition there is a clear need for basic data from the Filchner-Ronne ice shelf.

RÉsumé. Les plateformes de glace: un tour d'horizon. Les plateformes se forment lorsque de la glace s'écoule de la calotte glaciaire de l'Antarctique vers la mer pour produire des plaques assez plates de glace flottante qui pour les théoriciens sont les plus simples de toutes les grandes masses de glace. Les conditions aux limites sont bien définies, ces conditions varient très lentement sur des distances qui sont grandes en comparaison de l'épaisseur de la glace et les vitesses horizontales sont indépendantes de la profondeur. Des plateformes non limitées peuvent être utilisées comme un gigantesque appareil de mesure pour étudier la loi d'écoulement de la glace sous de faibles contraintes. Plus loin vers le continent, lorsque le mouvement est gêné par des obstacles comme des domes insulaires de glace ou par le cisaillement entre la plateforme et ses rives, celle-ci transmet une pression résistante qui tend a restreindre l'écoulement depuis la calotte glaciaire qui la nourrit. Les pertes de la plateforme sont principalement les vêlages et la fusion au fond. Il n'y a pas eu de mesures directes de fusion au fond mais des preuves indirectes montrent que, près du côté tourné vers la mer de la plateforme, la fusion au fond peut atteindre $\mathrm{I} \mathrm{m} / \mathrm{an}$ avec une fusion significative jusqu'à $\mathrm{I}$ oo $\mathrm{km}$ du front de glace. Plus loin vers le continent il peut y avoir regel au fond et des analyses de carottes prélevées de l'Amery Ice Shelf indiquent que la vitesse de regel au fond est en moyenne de $0,5 \mathrm{~m} / \mathrm{an}$ sur une distance de $200 \mathrm{~km}$. Une telle importance du regel est probablement exceptionnelle et sous le Ross Ice Shelf, le regel apparait comme insignifiant même à une distance de $400 \mathrm{~km}$ du front de glace.

Grâce à leur accessibilité les plateformes ont été étudiées très en détail mais bien des problèmes subsistent. En particulier nous devons améliorer notre compréhension du flux au fond de la dynamique de la plateforme près de la ligne de décollement, du vêlage des icebergs et de l'état d'équilibre des môles de glace. En sus il y a un besoin évident de données de base en provenance de la plateforme de Filchner-Ronne.

Zusammenfassung. Schelfeise: eine Übersicht. Schelfeise entstehen dort, wo Eis aus dem antarktischen Eisschild ins Meer fliesst und dabei weitgehend flache Tafeln schwimmenden Eises bildet, die - theoretische gesehen - die einfachste Form grosser Eismassen darstellen. Die Randbedingungen sind klar definiert, die Verhältnisse ändern sich nur allmählich über Entfernungen, die im Vergleich zur Eisdecke gross sind, und die Horizontalgeschwindigkeiten sind unabhängig von der Tiefe. Unbegrenzte Schelfeise können als gewaltige Kriechapparate zur Untersuchung des Eis-Fliessgesetzes bei geringen Spannungen benutzt werden. Weiter landeinwärts, wo die Bewegung durch Hindernisse wie aufsitzende Eiserhebungen und durch Scherkräfte zwischen dem Schelfeis und seiner Umrahmung gehemmt ist, überträgt das Schelfeis enen Rückdruck, der den Ausfluss aus dem ernährenden Eisschild einzuschränken sucht. Der Abbau des Schelfeises erfolgt im wesentlichen durch Kalben und durch Abschmelzen an der Unterseite. Es gibt keine direkte Messung von Schmelzraten an der Unterseite, doch deuten indirekte Anzeichen darauf hin, dass nahe an der Front von Schelfeisen die Schmelzraten $1 \mathrm{~m}$ pro Jahr überschreiten können und dass innerhalb der ersten $100 \mathrm{~km}$ hinter der Eisfront beträchtliches Abschmelzen stattfindet. Weiter landeinwärts kann Anfrieren an der Unterseite eintreten; Analysen von Kernen aus dem Amery Ice Shelf deuten darauf hin, dass die Anfrierraten an der Unterseite im Mittel $0.5 \mathrm{~m}$ pro Jahr auf eine Distanz von $200 \mathrm{~km}$ betragen. Solch hohe Anfrierraten bilden vermutlich die Ausnahme; unter dem Ross Ice Shelf dürfte das Anfrieren selbst in Entfernungen bis $400 \mathrm{~km}$ von der Eisfront nur unwesentlich sein.

Wegen ihrer Zugänglichkeit wurden Schelfeise sehr eingehend untersucht, doch bleiben noch viele Probleme. Im einzelnen ist ein besseres Verständnis der Fliessvorgänge in der Tiefe, der Schelfeis-Dynamik nahe der Aufsetzlinie, des Kalbens von Eisbergen und des Gleichgewichtszustandes von Eiserhebungen erforderlich. Ausserdem liegt ein dringendes Bedürfnis nach grundlegenden Daten über das Filchner-RonneSchelfeis vor. 


\section{INTRODUGTION}

Ice shelves are floating ice sheets that are attached either to land or to a grounded ice sheet. They are nourished by snow accumulation and by the seaward extension of land glaciers. In exceptional circumstances the freezing of ice onto the bottom of the ice shelf is the main source of accumulation. Wastage is mainly by melting from the base of the ice shelf and by calving from the ice front to produce icebergs. In general, loss by melting at the upper surface is insignificant. Where an ice shelf runs aground locally it slows down and tends to thicken. If the grounded area is sufficiently small, then the ice shelf may slide over the rock bed. Generally, however, the ice shelf flows around the grounded area, usually with the accompaniment of massive crevassing (Fig. I). The grounded ice is then known as an ice rise and it has its own flow pattern which is determined by grounded-ice dynamics.

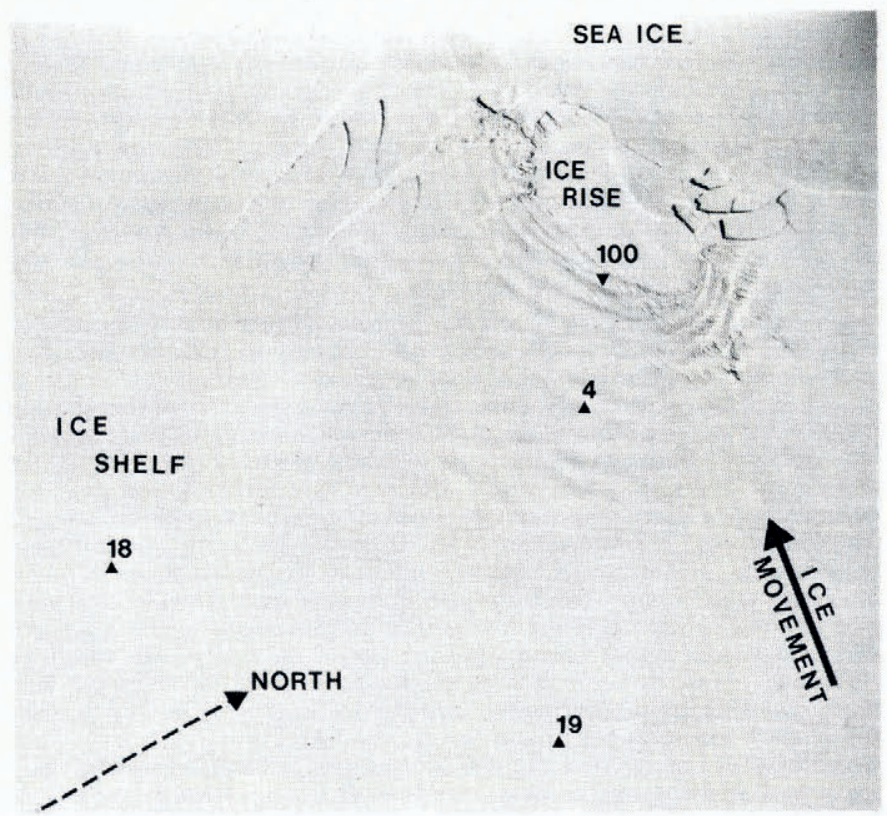

Fig. I. Air photograph, taken from 8 ooo $m$, of a small ice rise on the Brunt Ice Shelf. The distance between stations 18 and 19 is $5 \mathrm{~km}$.

Up-stream from an ice rise or where a glacier or an ice stream enters the ice shelf, large pressure ridges may form, but, in general, the ice-shelf surface appears to be completely flat. Wherever detailed measurements are made, however, the surface is shown to consist of a series of undulations with wavelengths of $\mathrm{I}-\mathrm{I}$ o $\mathrm{km}$ and wave heights of $\mathrm{I}-5 \mathrm{~m}$. In some cases pronounced waves are aligned at $45^{\circ}$ to the direction of flow and these appear to be associated with shear between ice-shelf "streams" that are moving at different speeds. Often, the larger depressions occur over crevasses in the bottom surface of the ice shelf. The more subdued waves that persist over almost the entire ice shelf are usually aligned with their crests perpendicular to the direction of flow, and at present there is no satisfactory explanation for their formation.

Almost all present-day ice shelves are in the Antarctic where they partially fill all the major embayments and occupy about ten per cent of the surface area of the ice sheet (Fig. 2). Since most of the land glaciers and ice streams flow into these embayments, ice shelves act as outlets for more than half of the drainage from the Antarctic ice sheet. 


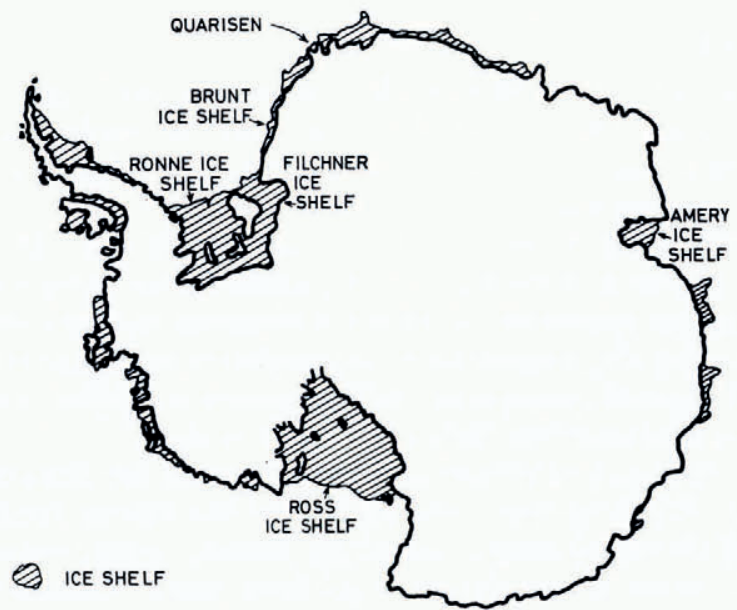

Fig. 2. A map of Antarctica showing the major ice shelves. In the text Quarisen will be referred to as Maudheim Ice Shelf since it has been much discussed in the literature under this name.

Movement-rates are commonly of the order of hundreds of metres per year and, near the fronts of the larger ice shelves, speeds of more than one kilometre per year have been measured. The two largest ice shelves, the Ross Ice Shelf and the Filchner-Ronne Ice Shelf, are each about the size of Spain. At their inland margins, ice thicknesses up to I $300 \mathrm{~m}$ have been recorded. The thickness decreases to about $200 \mathrm{~m}$ at the ice front by the ice shelf spreading under its own weight and also by basal melting. Snow accumulation-rates range from less than $0.1 \mathrm{~m}$ of ice per year on parts of the Ross Ice Shelf to almost $0.5 \mathrm{~m} \mathrm{a}^{-1}$ on ice shelves that fringe the Weddell Sea. In some cases, basal melting is so pronounced that all of the ice flowing from the inland ice sheet melts away to leave an ice-shelf fringe near the ice front. Such a fringe is derived entirely from snow that fell on the shelf (Fig. 3).

Ice-shelf morphology has been well described by Wright and Priestley (1922) and by Swithinbank (1957[a]), and these works have been excellently summarized by Swithinbank and Zumberge (1965). In this paper I shall confine myself to the aspects of ice-shelf behaviour that are likely to be of most interest to glaciologists: mass balance and basal melting, ice-shelf creep, and the interaction between ice shelves and ice sheets. In the final section I shall list recommendations for future field work that may help to solve some of the outstanding problems. But first I shall review briefly the relevant field work.

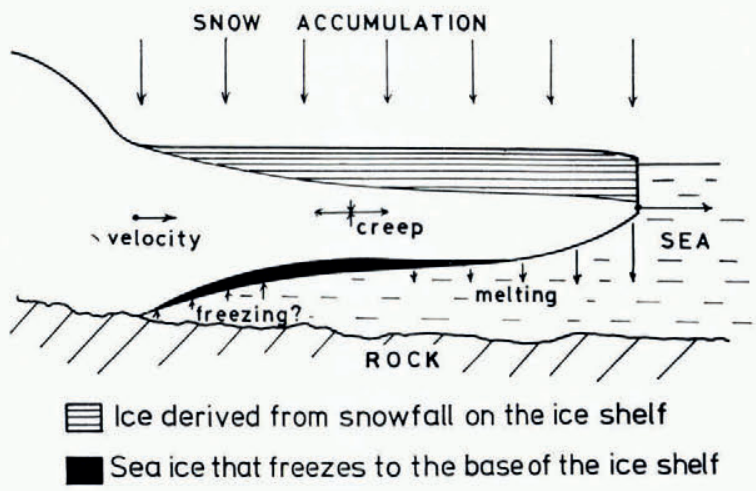

Fig. 3. Generalized section of an ice shelf. 


\section{Field WORK ON IGE SHELVES}

Although ice shelves are a very effective barrier to seaborne exploration, their flat, relatively crevasse-free surfaces provide excellent highways for surface access to the heart of Antarctica, particularly so for the early attempts to reach the South Pole. Indeed, the first major contribution to our knowledge of ice shelves was that of Wright and Priestley (1922) in their report of the glaciological results of Scott's last expedition. These writers considered ice shelves to be representative of the "zone of balanced forces" where snow accumulation is exactly compensated by ice spreading, so that ice thickness tends to achieve an equilibrium value that is determined by the temperature, accumulation-rate, and the extent to which the ice shelf is confined. A natural consequence of this process is the flat, almost horizontal upper surface that is the most characteristic feature of all ice shelves.

Little was added to the work of Wright and Priestley until the Norwegian-British-Swedish Expedition of $1949-52$. Working from a station on the Maudheim Ice Shelf this group made measurements of ice thickness by seismic sounding (Robin, 1958), firn stratigraphy in a deep pit (Schytt, 1958[b]), snow accumulation-rates from stake measurements (Swithinbank, 1957[b]) and the rate of spreading of the ice shelf (Swithinbank, I958). In addition, cores from a $100 \mathrm{~m}$ bore hole were examined for density variations and crystal size and $c$-axis orientation (Schytt, I958[a]). Temperature measurements in the hole showed a gradual, but accelerating increase with depth (Schytt, I96o). During the International Geophysical Year (1957-58), work similar to that completed at Maudheim was attempted on both the Filchner Ice Shelf (Behrendt, I962) and the Ross Ice Shelf (Crary, I96r ; Crary and others, I962), and a hole was bored completely through the Ross Ice Shelf (Gow, I963).

Detailed investigations by each of these groups were made near the ice front, where the ice shelf was comparatively unrestricted. Measurements at three stations along the centreline of the Amery Ice Shelf (Budd, I966; Budd and others, I967) gave important information on the behaviour of an ice shelf that flows between roughly parallel flanks of grounded ice. The influence of a grounded ice rise on ice-shelf dynamics was investigated by Thomas (1973[a]) using the results of detailed measurements made along a flow line through the Brunt Ice Shelf. These data also provide information on the ice flow law at low stresses (Thomas, I973[a]) and on the variation of basal-melting rate along the flow line (Thomas and Coslett, I970).

The most recent phase in ice-shelf investigation involves what is probably the most ambitious glaciological project ever attempted, the Ross Ice Shelf Project (RISP). As originally conceived, RISP involved the drilling of a hole through the Ross Ice Shelf to investigate the ice, the underlying sea-water, and the ocean floor (Zumberge, 1971). A programme of seismic sounding over the surface of the ice shelf was included to assist with selection of the drill-hole site. As the planning for RISP continued it became apparent that the programme of surface observations should include other geophysical and glaciological measurements, and that its scientific importance merited a separate logistic effort. The project that grew from these beginnings was the Ross Ice Shelf Geophysical and Glaciological Survey (RIGGS); it involved measurements at approximately I8o locations which are $55 \mathrm{~km}$ apart and form a grid network over the entire ice shelf (Fig. 4). Field work at each station included seismic sounding of the ice thickness and sea-bed depth, radio echo-sounding for ice thickness and the investigation of reflecting layers within the ice shelf, measurement of local gravity, and glaciological observations comprising measurements of surface strain-rates and snow accumulation-rates. At some of the stations, holes ten metres deep were drilled for oxygenisotope analysis, beta-particle scanning of the snow core, and for measurement of ten-metre snow temperatures. Artificial-satellite tracking at each of these stations gave a precise fix that could be compared with a subsequent fix to give absolute ice velocity. Other RIGGS programmes include tidal measurements on the ice shelf, and surface-snow chemistry investigations into precipitation-forming mechanisms. 


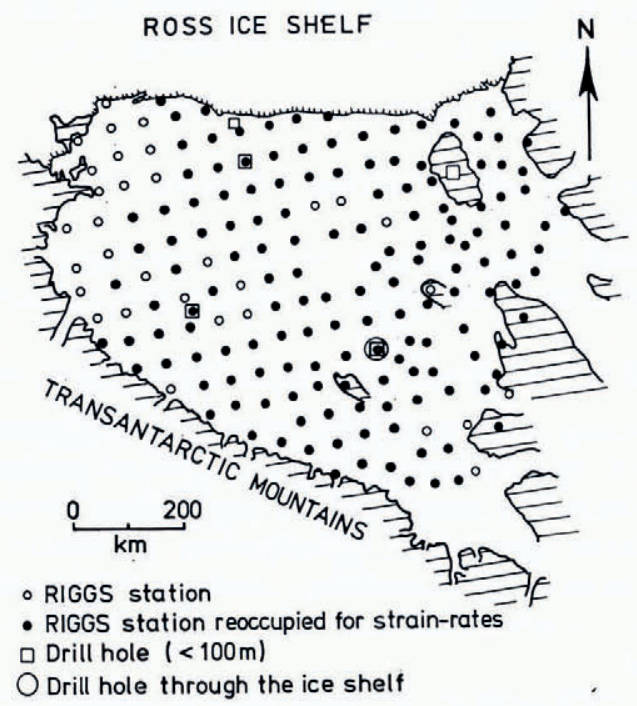

Fig. 4. The Ross Ice Shelf, showing positions of RIGGS stations where measurements have been made of ice thickness, depth to seabed, local gravity, snow accumulation-rates, ice velocity, and strain-rates.

The RIGGS field programme has occupied four Antarctic summers between 1973 and 1978. Nearly all of the planned stations have been established and most of these have been reoccupied for the measurement of strain-rates and ice velocity. Reports of field work have been published in the Antarctic Fournal of the United States; data analysis and interpretation are still continuing and abstracts of preliminary results were published in the April 1978 edition of Eos (Vol. 59, No. 4).

The main thrust of RISP remains the drilling programme, and a hole which penetrates the ice shelf completely at a point that is more than $400 \mathrm{~km}$ from the ice front (Fig. 4) was successfully opened in December 1977. A television camera lowered down the hole provided what was certainly the most spectacular discovery: the existence of several amphipods, one isopod, and two species of fish within the water column beneath the ice shelf. Although this may not be of immediate glaciological interest, a more detailed analysis of ocean population beneath the ice shelf may help in the identification of sediments that were deposited beneath former ice shelves. A programme of core recovery and temperature measurements has been completed through part of the ice-shelf thickness, and this will be continued during the 1978-79 field season. Meanwhile, shallow holes up to $100 \mathrm{~m}$ in depth have been cored at four other sites on the ice shelf (Fig. 4).

Investigation of the bottom surface of the ice shelf also forms part of the RISP programme. At the time of writing no direct observation of basal flux has been made, and preliminary analyses of down-hole measurements of ice temperature and of sea current, temperature, and salinity beneath the ice shelf are inconclusive, indicating only that bottom freezing- or meltingrates in the vicinity of the bore hole are very small.

\section{BALANGE STUDIES AND BOTTOM MELTING}

\section{Ice-shelf equilibrium}

Most ice shelves are fed by ice flowing off the grounded portion of the Antarctic ice sheet, and the state of equilibrium of an ice shelf may give us some idea of what is happening to the nearby ice sheet. Unfortunately, however, the relationship between ice-shelf equilibrium and 
ice-sheet equilibrium is by no means clear cut. For instance, an ice shelf that is growing thicker may be doing so in response to any of the following causes:

I. Increase in drainage from the ice sheet that is caused by accelerated thinning and icesheet collapse.

2. Increase in drainage that reflects increased snowfall over the ice sheet, with the possibility of ice-sheet growth.

3. Alteration in ice-shelf dynamics that causes a reduction in creep-rates, and which ultimately may tend to dam drainage from the ice sheet and initiate a period of ice-sheet growth.

4. Increase in snowfall or decrease in bottom-melting rates on the ice shelf.

The variation of thickening-rate with position on the ice shelf gives some indication of what is causing the non-equilibrium behaviour. However, further clarification requires additional information from the grounded ice sheet, and the results from ice-shelf studies serve to highlight the areas on the ice sheet that require investigation. Moreover, because ice shelves float on a virtually frictionless surface with conditions uniform over distances that are large compared to ice thickness, the interpretation of ice-shelf measurements is comparatively straightforward and unambiguous.

At any geographically-fixed point an ice sheet tends to thicken, generally by snow accumulation, basal freezing, and horizontal advection of thicker ice from up-stream. This tendency is, to some extent, balanced by creep thinning and by bottom melting. If there is unbalance then the ice-sheet thickness changes with time. The formal expression of this process is known as the equation of continuity and, for grounded ice sheets, its solution is complicated by lack of information concerning velocity and strain-rates beneath the surface. However, floating ice shelves rest on a frictionless bed so that velocity and strain-rate measurements made at the surface are closely representative of what is happening at depth. Under these conditions the continuity equation can be solved at any position on the ice shelf by making local measurements of snow-accumulation rate, ice velocity, surface strain-rates, ice thickness, and thickness slope in the direction of ice movement. This final measurement is of particular importance on ice shelves where ice velocities are generally high, so that ice advection can become the dominant term in the continuity equation. Unfortunately, the precise direction of ice movement is seldom known at the time that ice thickness is measured, so that the thickness slope is usually interpolated from nearby measurements. Moreover, ice shelves typically possess gently undulating top and bottom surfaces, and thickness slopes measured over distances of the order of the ice thickness differ considerably from measurements made over larger distances. These uncertainties introduce unknown errors into the solution of the continuity equation.

Where data are collected from a network of stations, errors may be reduced and documented by considering the volume continuity of a band of ice shelf that is bounded laterally by flow lines. The volume of ice entering and leaving the band can be calculated from measurements of ice velocity and thickness, and the volume of ice added by snow accumulation is obtained from measurements of accumulation-rate. Imbalance between the volumes of ice added to the band and leaving the band gives a measure of ice-shelf thickening-rate and/or bottom-melting rate averaged over the band. This analysis has been applied to several flow bands through the Ross Ice Shelf using data from the RIGGS (Thomas and Bentley, I978).

\section{Bottom melting or freezing}

Whilst the oceanographer is interested in bottom-melting rates, the glaciologist is most interested in ice-shelf thickening-rates, and in order to proceed further it is necessary to separate these two parameters. Unfortunately this is difficult; indeed bottom-melting rates 
have never yet been measured by any direct means. Clearly, by assuming steady-state (no change in thickness with time), bottom-melting rates can be estimated from the continuity equation, and this has been done for several ice shelves (Swithinbank, 1958; Crary, r96r ; Thomas and Coslett, 1970). Occasionally, the steady-state assumption can be checked by re-measuring a thickness or surface elevation profile (Swithinbank, [1962]; Crary, r964; Coslett and others, I 975). However, thickness changes must be greater than about ten or one metres respectively for detection by radio echo-sounding or optically-levelled re-surveys. Thus, the surveys must be separated by several years in order to detect changes of the order of a few tenths of a metre per year.

Where a hole is drilled through the ice shelf alternative methods of estimating basal flux are available. The form of the temperature-depth curve is partly determined by the basal flux (Crary, I96I; Shumskiy and Zotikov, I963), but, unfortunately, the analysis becomes almost intractable as soon as the steady-state assumption is abandoned; numerous "reasonable" solutions exist corresponding to different assumed ice-shelf histories. A layer of sea-ice frozen onto the bottom of the ice shelf can be detected by core analysis (Morgan, I972), but the presence of such a layer does not necessarily imply that basal freezing is taking place at the core hole: only that the layer was frozen onto the ice shelf somewhere up-stream of the hole. Moreover, rigorous checks must be made to ensure that the hole is not bored into sea ice that has formed in an old bottom crevasse (Clough and others, 1975).

Measurements of salinity, temperature, and current velocity beneath the ice shelf can also give an indication of bottom-melting or -freezing rates since the heat and salinity balance of sea-water is affected by the basal flux. Such measurements should be made over a period that is long enough to allow evaluation of the full effects of tidal pumping. Direct measurement of basal flux requires access to the bottom of the ice shelf and this is most easily gained via a bore hole. Experiments that have been proposed for the RISP bore hole include the repeated mapping of the ice-shelf base in the region of the bore hole by an ultrasonic sounder suspended beneath the ice shelf, and the implanting of markers in the base of the ice shelf to record freezing or melting directly.

For obvious reasons, remote-sensing methods of investigating the internal properties and basal characteristics of ice shelves provide an attractive alternative to direct measurement. The measurement of basal flux by remote sensing is still in its infancy but two approaches have been attempted and both show considerable promise. Resistivity measurements at the surface of the ice shelf give a measure of the distribution of ice temperature with depth which in turn can be interpreted in terms of the basal flux. Observations on the Ross Ice Shelf (Bentley, 1977, Bentley and Shabtaie, I978) give a temperature-depth curve that shows good agreement with the measured values, and improvements in the technique may yield corresponding "steady-state" values of basal flux with an accuracy of about $\pm 0.1 \mathrm{~m} \mathrm{a}^{-1}$.

A second and potentially very powerful technique involves radio echo-sounding. The absorption of radio waves in ice is strongly dependent on the concentration of impurities in the ice and on the ice temperature. Thus, by measuring the strength of the signal reflected from the base of the ice shelf during aerial radio echo-sounding flights, a contour map showing isolines of radio-wave absorption can be obtained (Neal, I979). This requires correction for an assumed ice temperature-depth curve to give the distribution of zones that contain high concentrations of impurities, and which may represent ice shelf with a layer of sea ice frozen to its base. Clearly the interpretation is not without its problems; the temperature correction introduces errors, and the impurity-rich zones may be due to brine infiltration via crevasses that form in the base of the ice shelf at the points of entry of ice streams and glaciers. Nevertheless, Neal (1979) has attempted to map areas of the Ross Ice Shelf that possess frozen-on basal sea ice. Undoubtedly, this technique deserves more attention, but the test of its effectiveness must await information from bore holes that sample both high- and low-impurity zones within the ice shelf. 
The measurement of basal flux is clearly important if we are to determine rates of ice-shelf thickening or thinning, but it also has glaciological ramifications that are not immediately apparent. For instance, Shumskiy and Krass (1 976) propose that the effects of basal freezing, allied with the effects of heat generation by creep, could be sufficient, given appropriate conditions, to cause thermal instability with ice melting within the ice shelf. Although it is unlikely that any real ice shelf could satisfy the conditions required to initiate this instability, the influence of basal flux on ice temperatures can have a significant effect on ice-shelf dynamics. An ice shelf with basal freezing is warmer (and therefore softer) than one under similar conditions but with basal melting, and the more sophisticated attempts at ice-shelf modelling should include this effect.

To a geologist the pattern of basal flux is important since it determines the pattern of deposition of material from the base of the ice shelf. Deposition can take place only in an area of basal melting and only after any protective layer of sea ice has been removed. Numerous sedimentary sequences are believed to have been deposited beneath an ice shelf (Carey and Ahmad, r96r) and, with the help of a fuller understanding of freezing-melting patterns beneath existing ice shelves, these sequences may become powerful aids in the interpretation of past glaciations. For the larger ice shelves, the picture that emerges from existing studies includes bottom melting near the ice front of one metre or more of ice per year, with significant melting within perhaps $100 \mathrm{~km}$ of the ice front. Further "inland" the picture is confused; on the Amery Ice Shelf there may be basal freezing of about $0.5 \mathrm{~m}$ per year (Wakahama and Budd, I976), but on the Ross Ice Shelf significant basal freezing appears to be confined to flow bands corresponding to major glaciers and ice streams that drain into the ice shelf (Neal, I979).

\section{Dynamics}

Ice shelves as creep machines

Stresses in glaciers and ice shelves are typically of the order of o.I $\mathrm{MN} \mathrm{m}^{-2}$ (one bar) or less, and laboratory experiments at these low stresses become both unreasonably timeconsuming and unreliable. This is particularly so at temperatures less than $-10^{\circ} \mathrm{C}$ where, for instance, a uniaxial stress of $0.05 \mathrm{MN} \mathrm{m}^{-2}$ produces a strain-rate of less than $\mathrm{Io}^{-3} \mathrm{a}^{-1}$. In this stress region, field glaciology is likely to provide more information, but difficulties arise in the interpretation of glacier behaviour either from the use of an over-simplified theoretical model, or from lack of knowledge of all the relevant field data. However, these disadvantages apply less to ice shelves, which rest on a frictionless bed of known temperature, so that ice velocities and strain-rates are independent of depth* and the surface boundary conditions are well defined.

It was evident to the early explorers that ice shelves spread outwards under the influence of their own weight (Wright and Priestley, 1922) but it was not until comparatively recently that a formal analysis of ice-shelf creep was attempted. Robin (1958, p. I I4) showed how the longitudinal stress varies with depth, and Weertman's (1957) elegant analysis yielded a simple and easily-tested relationship between longitudinal strain-rate $\dot{\epsilon}$ and ice thickness $H$

$$
\dot{\epsilon}=K\left(\rho_{\mathrm{i}} g \Delta \rho H\right)^{n},
$$

where $\rho_{\mathrm{i}}$ is the density of the ice shelf (assumed, for simplicity, to be independent of depth), $\Delta \rho=\left(\mathrm{I}-\rho_{\mathrm{i}} / \rho_{\mathrm{w}}\right)$ with $\rho_{\mathrm{w}}=$ density of sea-water, $K$ is a function of ice fabric, temperature, and the ratio between the components of the strain-rate tensor, and $n$ is the exponent in

* This is strictly true only for ice shelves of uniform thickness. For a sloping ice shelf there is a very small component of horizontal shear in the vertical plane. Calculations suggest that, at the site of the RISP drill hole, an initially vertical hole would become bowed to the extent that, after a year, its maximum deviation from vertical would be less than one millimetre. 
Glen's ice flow law. Apart from $n$ and the temperature and fabric-controlled portions of $K$ all the components of this equation can be measured, so that data from ice shelves with differing thickness can be used to examine the flow law for "natural" ice. The results (Thomas, I 973[a]) suggest that the laboratory flow law for polycrystalline ice (Glen, I955; Steinemann, [1956]; Barnes and others, I 97I) can be applied with $n \approx 3$ at stresses down to $0.04 \mathrm{MN} \mathrm{m}^{-2}$ and probably at stresses as low as o.o I $\mathrm{MN} \mathrm{m}^{-2}$. It is important to note that these results apply only to ice shelves. Portions of a grounded ice sheet, and even parts of an ice shelf, that are subject to prolonged shear may develop a preferred fabric that softens the ice for the prevailing stress (Paterson, 1977).

\section{Bounded ice shelves}

Weertman's (1957) analysis predicts that longitudinal strain-rate $\dot{\epsilon}$ will increase rapidly with increasing ice thickness, but Budd ( 1966 ) reported observations on the Amery Ice Shelf showing the opposite trend, with $\dot{\epsilon}$ decreasing almost to zero as the ice thickness (and distance from the ice front) increased. The Amery Ice Shelf lies between two almost parallel flanks of land, and Budd suggested that part of the driving force is used to push the ice shelf past its sides. Since the driving force is proportional to the weight of ice above sea-level the ice thickness increases away from the ice front, and this feature was considered by Crary (1966) to be responsible for overdeepening at the inland end of fjords. Weertman's analysis of iceshelf creep has been generalized to include the effects of back-pressure $P$ that is exerted on the ice shelf by its margins and by obstacles to flow such as grounded ice rises (Thomas, 1973[b]). Equation (I) then becomes:

$$
\dot{\epsilon}=K\left(\rho_{1} g \Delta \rho H-2 P\right)^{n} .
$$

This equation can be used to investigate the interaction between an ice shelf and its sides, to calculate the compressive stresses that exist up-stream of ice rises, and to construct hypothetical ice-shelf profiles under prescribed boundary conditions (Sanderson, 1979).

Analysis of existing data suggests that, in general, the shear stress between an ice shelf and its sides is in the range 0.06-0. $\mathrm{MN} \mathrm{m}^{-2}$, which is in good agreement with the value associated with a "plastic yield stress" for ice (Paterson, I969, p. 88). However, there appears to be a tendency for the shear stress to decrease as the ice-shelf velocity increases. Where the floating portion of Byrd Glacier flows, at about $0.8 \mathrm{~km} \mathrm{a}^{-1}$, between rock walls that are $30 \mathrm{~km}$ apart the shear stress at the sides is calculated to be $0.04 \mathrm{MN} \mathrm{m}^{-2}$. This may represent the development of a band of ice with a preferred crystal fabric in the zone of intense shear near the iceshelf margins (Hughes, I 977). Figure 5 shows a generalized bounded ice shelf containing ice rises. Compressive stresses immediately up-stream of the ice rises can be significantly higher than shear stresses at the sides. Within about $\mathrm{I} \mathrm{km}$ of a small ice rise on the Brunt Ice Shelf (Fig. I), compressive stresses were calculated to exceed I $\mathrm{MN} \mathrm{m}^{-2}$ (Thomas, I973[a]). Thus, even small ice rises act as pinning points and buttress the ice shelf. Seaward of the ice rises the compressive stresses are removed and the ice shelf is able to spread and to fracture. Under these conditions the ice shelf is ripe for calving to produce icebergs which frequently exceed $100 \mathrm{~km}^{2}$ in area. Except within comparatively small areas immediately up-stream of ice rises most ice shelves tend to accelerate as they move toward the sea. This means that the longitudinal strain-rate $\dot{\epsilon}$ is either positive or close to zero so that, from Equation (2),

$$
\rho_{\mathrm{i}} g \Delta \rho H \geqslant 2 P \text {. }
$$

Any increase in the back-pressure $P$ acting on the ice shelf results in an increase in ice thickness $H$. Clearly, if the sea bed is sufficiently close to the base of the ice shelf, then increasing ice thickness causes progressive grounding of the ice shelf. A decrease in $P$ causes an increase in strain-rates so that the ice shelf tends to thin. If this happens near the ice-shelf grounding line 
then ungrounding may occur, with the ice shelf growing in size at the expense of its neighbouring ice sheet. This interaction is particularly important when the ice sheet is a "marine ice sheet", resting on rock that is below sea-level. The dynamics of marine ice sheets form the topic of a separate paper in this volume (Thomas, I979), but in the next section I shall briefly discuss the influence of ice shelves on the stability of marine ice sheets.

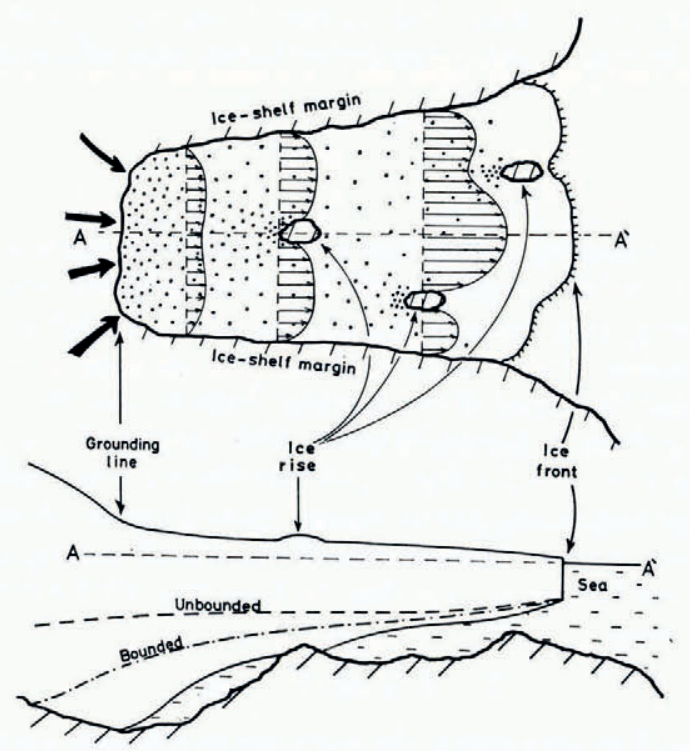

Fig. 5. Generalized plan and section of a bounded ice shelf with ice rises. Velocity profiles are shown for three sections across the ice shelf. The stippling indicates the presence of back-pressure exerted on the ice shelf by the margins and ice rises. The intensity of the stippling gives an indication of the relative magnitude of the back-pressure. Three bottom profiles are shown; the solid line is for the bounded ice shelf with ice rises and the others are for bounded and unbounded ice shelves without ice rises. The position of the grounding line is strongly dependent on the type of ice shelf that forms.

\section{The interaction between ice shelves and ice sheets}

The position of the grounding line between an ice sheet and an ice shelf is determined by ice thickness and by sea depth. An increase in ice thickness or a decrease in sea depth causes grounding-line advance; opposite trends cause retreat. Advance is halted by a sufficiently steep down-slope in the sea bed, such as occurs at the edge of the continental shelf. Retreat is halted where the sea bed becomes sufficiently shallow, and in particular where it rises above sea-level to support a "terrestrial ice sheet". The Ross Ice Shelf is fed by both a marine ice sheet, in West Antarctica, and a terrestrial ice sheet, in East Antarctica. In this case, ice-shelf thinning would result in only a minor retreat of the valley glaciers that flow through the Transantarctic Mountains, but it could cause major retreat of the West Antarctic ice.

Ice-sheet growth and decay can, of course, take place in response to changes in climate, snow accumulation, or the mode of flow of the ice sheet, but here I shall consider only the influence of changes in ice-shelf dynamics. We can focus our attention on what influences the thickness $H$ of the ice shelf at the grounding line: the conclusions from the last section indicate that the major influence is $P$, the back-pressure due to shear stress between the ice shelf and its sides and to obstructions to movement such as grounded ice rises. If $P$ increases then the ice shelf grows thicker and the grounding line advances; a reduction in $P$ causes the opposite trends. The factors that affect $P$ can be grouped according to the response of the grounding line. 
Grounding-line advance is favoured by:

I. An increase in the size of the ice shelf, so that ice flowing across the grounding line has to push a larger ice shelf past its margins.

2. An increase in ice-shelf thickness. This also increases the total shear between the ice shelf and its sides, and it increases the tendency of the ice shelf to run aground and to form ice rises.

3. A fall in sea-level or a rise in sea bed. This has an immediate effect at the grounding line, where hydrostatic equilibrium must be maintained, and it has a delayed effect if new ice rises form within the ice shelf.

4. Cooling of the ice shelf so that the ice becomes stiffer.

Grounding-line retreat is favoured by:

I. A decrease in ice-shelf size or thickness.

2. Rising sea depth.

3. Ice-shelf warming.

4. A reduction in the shear stress between the ice shelf and its sides. This is probable during ice-sheet collapse when ice velocity may increase to many times its equilibrium value.

In short, a bounded ice shelf that is fed by a marine ice sheet can be regarded as a plug that is holding the ice sheet in place; removal or weakening of the plug may be followed by collapse of the ice sheet. Indeed Mercer ( 1968 ) suggests that the high sea-level of the last interglacial resulted mainly from deglaciation of the West Antarctic when the temperatures there rose above the level at which the ice shelves could survive. Moreover, Mercer (1978) warns of the possibility that the levels of atmospheric carbon dioxide, which are increasing at the moment, may lead to climatic warming that is sufficiently enhanced at high latitudes to cause once again the demise of the ice shelves and the inevitable collapse of the West Antarctic ice sheet; such changes could result in a five-metre rise in sea-level. This warning cannot be dismissed lightly since it is undoubtedly the case that the West Antarctic ice sheet is buttressed by ice shelves, and it is equally true that these ice shelves are highly susceptible to changes in climate. Mercer ( 1978 ) suggests that there is an urgent need for a sophisticated modelling of the climatic response to a changing level of atmospheric carbon dioxide. I would suggest that there also is a need for improvement in our understanding of the way in which an ice-shelf responds to changes in climate and of the way in which marine ice sheets respond to changes in the ice shelves. It is rare that the glaciological community has such a practical justification for what must appear to many to be our rather dilletante profession!

\section{CONGLUSIONS AND SUGGESTIONS FOR FURTHER WORK}

Until fairly recently ice shelves were regarded as no more than peripheral features of the Antarctic ice sheet, where they occupy the great embayments and serve to smooth the outline of the continent. Where ice flows off the ice sheet onto the sea it spreads out to produce a rather flat slab of floating ice and, when modeling the ice sheet, it is tempting to neglect this floating ice sheet and to define the edge of the ice sheet as the point where it becomes afloat. However, the very property of ice shelves that makes them spread out is also responsible for their usefulness and interest to the glaciologist. Ice shelves rest on an almost frictionless bed of known temperature, so that ice velocities and strain-rates are independent of depth and the boundary conditions are well defined. Moreover, because ice shelves are so flat, conditions change rather slowly over distances that are large compared with ice thickness. This means that theoretical models are likely to provide a good approximation to the behaviour of real ice shelves. Again, because the ice shelf is floating it is able to transmit stresses across large 
distances, so that any obstructions to flow, such as grounded ice rises, have a significant effect on ice at the grounding line between ice shelf and ice sheet. In this way an ice shelf may act as a dam, restricting outflow from the ice sheet and helping to preserve a state of equilibrium.

Because of their accessibility ice shelves have been studied in considerable detail and, on the Ross Ice Shelf, measurements of ice thickness, sea-bed topography, local gravity, snow-fall, ice velocity, and surface strain-rates have been made at approximately i8o locations. Near the ice front these data provide information on the flow law for natural ice; further inland they can be used to reconstruct stress distributions associated with ice rises and shearing of the ice shelf past its margins. Balance studies are complicated by lack of information from the base of the ice shelf-how much melting or freezing is taking place there? Indirect evidence suggests that, near the seaward edges of the larger ice shelves, bottom-melting rates may exceed one metre per year, with significant melting within about $100 \mathrm{~km}$ of the ice front. Further inland there may be bottom freezing. A drill hole in the Amery Ice Shelf revealed apparent bottom freezing of about $0.5 \mathrm{~m} \mathrm{a}^{-1}$, but evidence from a drill hole $400 \mathrm{~km}$ from the Ross Ice Front is suggestive of far lower freezing-rates. Remote-sensing techniques involving radio echosounding and the measurement of ice-shelf resistivity promise to improve our understanding of what is happening at the ice-water interface, but currently they provide rather poor resolution. Further development of these and any other methods for measuring bottom flux rank high on my list of recommendations for future field work. Other problems that deserve more attention include:

(i) Grounding-line dynamics. Field work should include detailed measurements of strainrates, accumulation-rates, ice velocity, and ice thickness at a network of stations that lie along the centre line of an ice stream and extend for several kilometres up- and down-stream from the grounding line. The position of the grounding line could be detected by making gravity measurements of tidal movement.

(ii) Ice-shelf fracture and calving mechanisms. Initial work should include a survey of the size distribution of icebergs that are produced in a given time. Mapping of major crevasses in both the top and bottom surfaces of ice shelves may provide approximate fracture criteria. Detailed work might involve the measurement of strain-rate gradients (with position and with time) near the ice front, and in an area where fracture is expected to occur.

(iii) Ice rises. The size of an ice rise is critically determined by the thickness of its surrounding ice shelf but, because the ice rise is grounded, it may continue to adjust its thickness for a long time after ice-shelf thickening or thinning has altered its area. In this way the ice rise retains a memory of ice-shelf history which may be revealed by measurement of its state of equilibrium.

(iv) Filchner-Ronne Ice Shelf. Very little is known about this ice shelf. On the Filchner Ice Shelf ice velocities are high (Lisignoli, I964) and, probably because there is a thick water column beneath this ice shelf, bottom-melting rates may be very high (Behrendt, I 970). In contrast to the Ross Ice Shelf the Ronne Ice Shelf contains many ice rises, and these are probably essential to its existence since there appear to be few major ice streams feeding the ice shelf. If the West Antarctic ice sheet has been shrinking then these ice rises currently may be collapsing, and the Ronne Ice Shelf would provide a good analogy to an earlier form of the Ross Ice Shelf. A RIGGS-type experiment would be particularly suitable here because we have little information on flow directions in the ice shelf. In addition the survey should include a detailed study of the ice rises in order to reveal their equilibrium state.

Clearly this is not a complete list, and I have deliberately omitted work involving drill holes because this involves such a large logistic commitment. Light-weight drilling equipment that is capable of penetrating $100 \mathrm{~m}$ or more will soon be readily available, but there is still 
a need for drill holes right through the ice shelf in order to study basal flux and to investigate conditions beneath the ice shelf. Finally, I stress the importance of applying the results from field work in order to test and improve theoretical models of ice shelves which are capable of predicting ice-shelf behaviour under prescribed conditions.

\section{Acknowledgements}

This work was partially supported by National Science Foundation grant DPP 76-23047 Aor, and it was completed while I was a Visiting Scholar at the Scott Polar Research Institute.

\section{REFERENCES}

Barnes, P., and others. 1971. Friction and creep of polycrystalline ice, by P. Barnes, D. Tabor, and J. C. F. Walker. Proceedings of the Royal Society of London, Ser. A, Vol. 324, No. 1557, p. 127-55.

Behrendt, J. C. 1962. Geophysical and glaciological studies in the Filchner Ice Shelf area of Antarctica. Fournal of Geophysical Research, Vol. 67, No. 1, p. 221-34.

Behrendt, J. C. 1970. The structure of the Filchner Ice Shelf and its relation to bottom melting. [Union Géodésique et Géophysique Internationale. Association Internationale d'Hydrologie Scientifique.] [International Council of Scientific Unions. Scientific Committee on Antarctic Research. International Association of Scientific Hydrology. Commission of Snow and Ice.] International Symposium on Antarctic Glaciological Exploration (ISAGE), Hanover, New Hampshire, U.S.A., 3-7 September 1968, p. 488-96. [(Publication No. 86 [de 1'Association Internationale d'Hydrologie Scientifique].)]

Bentley, C. R. 1977. Electrical resistivity measurements on the Ross Ice Shelf. Fournal of Glaciology, Vol. I8, No. 78 , p. $15-35$.

Bentley, C. R., and Shabtaie, S. 1978. Geophysical evidence for the mass balance at the ice/water boundary beneath the Ross Ice Shelf. Eos. Transactions, American Geophysical Union, Vol. 59, No. 4, p. 309. [Abstract.]

Budd, W. F. 1966 . The dynamics of the Amery Ice Shelf. Fournal of Glaciology, Vol. 5, No. 45, p. 335-58.

Budd, W. F., and others. 1967 . The Amery Ice Shelf, by W. [F.] Budd, I. [H.] Landon-Smith, and E. [R.] Wishart." (In Oura, H., ed. Physics of snow and ice: international conference on low temperature science. . . . 1966. . . Proceedings, Vol. I, Pt. I. [Sapporo], Institute of Low Temperature Science, Hokkaido University, p. 447-67.)

Carey, S. W., and Ahmad, N. I96r. Glacial marine sedimentation. (In Raasch, G. O., ed. Geology of the Arctic. Toronto, University of Toronto Press, Vol. 2, p. 865-94.)

Clough, J. W., and others. 1975. RISP drill site survey, [by] J. W. Clough, K. C. Jezek, and J. D. Robertson. Antarctic Journal of the United States, Vol. 10, No. 4, p. $148-49$.

Coslett, P. H., and others. I975. Optical levelling across an Antarctic ice shelf, by P. H. Coslett, M. Guyatt, and R. H. Thomas. British Antarctic Survey Bulletin, No. 4o, p. $55^{-6} 3$.

Crary, A. P. I96r. Glaciological studies at Little America Station, Antarctica, I957 and 1958. IG Y Glaciological Report Series (New York), No. 5. Crary, A. P. 1964. Melting at the ice-water interface, "Little America" Station. Fournal of Glaciology, Vol. 5,
No. 37, p. 1 $29-30$.

Crary, A. P. I966. Mechanism of fiord formation indicated by studies of an ice-covered inlet. Geological Society of America. Bulletin, Vol. 77, No. 9, p. 911-29.

Crary, A. P., and others. 1962. Glaciological studies of the Ross Ice Shelf, Antarctica, 1957-1960, by A. P. Crary, E. S. Robinson, H. F. Bennett, and W. W. Boyd, Jr. IGY Glaciological Report Series (New York), No. 6.

Glen, J. W. 1955. The creep of polycrystalline ice. Proceedings of the Royal Society of London, Ser. A, Vol. 228, No. 1175 , p. 519-38.

Gow, A. J. 1963. The inner structure of the Ross Ice Shelf at Little America V, Antarctica, as revealed by deep core drilling. Union Géodésique et Géophysique Internationale. Association Internationale d'Hydrologie Scientifique. Assemblée générale de Berkeley, 19-8-31-8 1963. Commission des Neiges et des Glaces, p. 272-84.

Hughes, T. J. 1977. West Antarctic ice streams. Reviews of Geophysics and Space Physics, Vol. I 5, No. I, p. 1-46.

Lisignoli, C. A. ${ }^{1} 964$. Movement of the Filchner Ice Shelf, Antarctica. Transactions of the American Geophysical Union, Vol. 45, No. 2, p. $391-97$.

Mercer, J. H. I968. Antarctic ice and Sangamon sea level. Union de Géodésie et Géophysique Internationale. Association Internationale d'Hydrologie Scientifique. Assemblée générale de Berne, 25 sept.-7 oct. 1967. [Commission des
[Com Neiges et Glaces.] Rapports et discussions, p. 217-25. (Publication No. 79 de 1'Association Internationale
d'Hydrologie Scientifique.)

Mercer, J. H. r 978 . West Antarctic ice sheet and $\mathrm{CO}_{2}$ greenhouse effect: a threat of disaster. Nature, Vol. 27I, No. 5643 , p. $321-25$.

Morgan, V. I. I972. Oxygen isotope evidence for bottom freezing on the Amery Ice Shelf. Nature, Vol. 238, No. 5364 , p. $393-94$. Neal, C. S. 1979. The dynamics of the Ross Ice Shelf revealed by radio echo-sounding. Fournal of Glaciology,
Vol. 24, No. 9o, p. $295-307$.

Paterson, W. S. B. I 969 . The physics of glaciers. Oxford, etc., Pergamon Press. (The Commonwealth and International Library. Geophysics Division.) 
Paterson, W. S. B. 1977. Secondary and tertiary creep of glacier ice as measured by borehole closure rates. Reviews of Geophysics and Space Physics, Vol. 15, No. I, p. 47-55.

Robin, G. de Q. I958. Glaciology. III. Seismic shooting and related investigations. Norwegian-British-Swedish Antarctic Expedition, 1949-52. Scientific Results, Vol. 5.

Sanderson, T. J. O. I 979 . Equilibrium profile of ice shelves. Fournal of Glaciology, Vol. 22, No. 88.

Schytt, V. 1958[a]. Glaciology. II. The inner structure of the ice shelf at Maudheim as shown by core drilling. Norwegian-British-Swedish Antarctic Expedition, 1949-52. Scientific Results, Vol. 4, C.

Schytt, V. 1958[b]. Glaciology. II. Snow studies at Maudheim. Norwegian-British-Swedish Antarctic Expedition, 1949-52. Scientific Results, Vol. 4, A.

Schytt, V. 196o. Glaciology. II. Snow and ice temperatures in Dronning Maud Land. Norwegian-BritishSwedish Antarctic Expedition, 1949-52. Scientific Results, Vol. 4, D.

Shumskiy, P. A., and Krass, M. S. 1976. Mathematical models of ice shelves. Fournal of Glaciology, Vol. I 7, No. 77, p. 419-32.

Shumskiy, P. A., and Zotikov, I. A. I963. O donnom tayanii shel'forvykh lednikov Antarktidy [Bottom melting of shelf ice of Antarctica]. (In Antarktika. Doklady Komissii, I962. Moscow, Izdatel'stvo Akademii Nauk SSSR, p. 87-108.) [English translation: Antarctica: Commission reports, 1962. Jerusalem, Israel Program for Scientific Translations, r 969, p. 90-1 12.]

Steinemann, S. [1956.] Flow and recrystallization of ice. Union Géodésique et Géophysique Internationale. Association Internationale d'Hydrologie Scientifique. Assemblée générale de Rome, 1954, Tom. 4, p. 449-62. (Publication No. 39 de l'Association Internationale d'Hydrologie.)

Swithinbank, C. W. M. r957[a]. Glaciology. I. The morphology of the ice shelves of western Dronning Maud Land. Norwegian-British-Swedish Antarctic Expedition, 1949-52. Scientific Results, Vol. 3, A.

Swithinbank, C. W. M. I957[b]. Glaciology. I. The regime of the ice shelf at Maudheim as shown by stake measurements. Norwegian-British-Swedish Antarctic Expedition, 1949-52. Scientific Results, Vol. 3 , B.

Swithinbank, C. W. M. 1958. Glaciology. I. The movement of the ice shelf at Maudheim. Norwegian-BritishSwedish Antarctic Expedition, 1949-52. Scientific Results, Vol. 3, C.

Swithinbank, C. W. M. [1962.] Maudheim revisited: the morphology and regime of the ice shelf, r950-1960. Norsk Polarinstitutt. Arbok, 1960, p. 28-31.

Swithinbank, C. W. M., and Zumberge, J. H. 1965. The ice shelves. (In Hatherton, T., ed. Antarctica. London, Methuen and Co., p. r99-220.)

Thomas, R. H. 1973[a]. The creep of ice shelves: interpretation of observed behaviour. Journal of Glaciology,

Vol. 12, No. 64, p. 55-70.
Thomas, R. H. r973[b]. The creep of ice shelves: theory. Fournal of Glaciology, Vol. 1 2, No. 64, p. 45-53.

Thomas, R. H. 1979. The dynamics of marine ice sheets. Journal of Glaciology, Vol. 24, No. 90, p. I67-77.

Thomas, R. H., and Bentley, C. R. 1978. The equilibrium state of the eastern half of the Ross Ice Shelf. Fournal of Glaciology, Vol. 20, No. 84, p. 509-18.

Thomas, R. H., and Coslett, P. H. 1970. Bottom melting of ice shelves and the mass balance of Antarctica.

Nature, Vol. 228, No. 5266, p. 47-49.
Wakahama, G., and Budd, W. F. I976. Formation of the three-layered structure of the Amery Ice Shelf, Antarctica. Journal of Glaciology, Vol. i6, No. 74, p. 295-97.

Weertman, J. 1957. Deformation of floating ice shelves. Fournal of Glaciology, Vol. 3, No. 21, p. $3^{8-42 .}$

Wright, C. S., and Priestley, R. E. 1922. Glaciology. London, Harrison and Sons, Ltd. (British Antarctic (Terra

Nova) Expedition, r9ro-1913.)
Zumberge, J. H. r971. Ross Ice Shelf Project. Antarctic Fournal of the United States, Vol. 6, No. 6, p. $258-63$. 